International Journal of Cardiology and Research (IJCRR)

ISSN 2470-4563

\title{
Iatrogenic Right Sided Infective Endocarditis in Children with CHD
}

Review Article

H.S.Natraj Setty*, Vijayalakshmi IB, Narasimhan C, Manjunath CN

Sri Jayadeva Institute of Cardiovascular Sciences and Research, Bangalore, Karnataka, India.

\section{Abstract}

Background: Right sided endocarditis (IE) occurs predominantly in intravenous drug abusers, and occasionally acquired in hospital as a result of contaminated intravascular devices. The iatrogenic IE of tricuspid valve in children treated with intravenous (IV) injections for various unrelated conditions is not reported in literature.

Objective: Aim is to report clinical outcome, microbiological and echocardiographic presentation of iatrogenic right sided IE in 4 children.

Materials and methods: In a span of 3 months four children, age ranging from 1 month to 5 years, three females and one male, who presented with prolonged history of fever formed the material for this study. Two cases had ventricular septal defect (VSD), one had a small atrial septal defect (ASD) and one patient had tetralogy of Fallot (TOF). The blood culture grew coagulase negative staphylococcus in two patients and gram negative bacilli in the one month infant. The diagnosis of tricuspid valve endocarditis was established by transthoracic echocardiography (TTE) in all the four patients. In addition to vegetation on tricuspid valve, the vegetation was also detected in inferior vena cava (IVC) in one case and in another case a large vegetation was seen closing the VSD.

Discussion: Right sided endocarditis accounts for only $5-10 \%$ of cases of IE. It has been estimated that up to $76 \%$ of cases of endocarditis among IV drug abusers involve the right heart, compared with only $9 \%$ in non-addict patients. The bacterial endocarditis is extremely rare in cases of ASD and TOF. This series of four cases is notable for the iatrogenic IE of tricuspid valve in children treated in the reputed hospitals with IV injections and IV fluids for various unrelated non cardiac conditions. The infection in this series occurred upon previously normal tricuspid valve. Three patients died $(75 \%)$ and only one survived.

Conclusions: Right sided endocarditis can occur in CHD patients when proper aseptic precautions are not taken while treating with IV injections. The blood culture and TTE play an important role in diagnosis and management of right sided IE.

Keywords: Tricuspid Valve; Intravenous Lines; Pulmonary Embolism; Coagulase Negative Staphylococcus; Inferior Vena Cava; Tetralogy of Fallot; Atrial Septal Defect; Ventricular Septal Defect.

\section{*Corresponding Author:}

Dr. H.S.Natraj Setty MD DM,

H.No $493,4^{\text {th }}$ cross $7^{\text {th }}$ main JP Nagar, $3^{\text {rd }}$ phase Bangalore 69, Karnataka, India.

Tel: 09845612322

Fax: 080-22977261

E-mail: drnatrajsetty75@gmail.com

Received: June 17, 2015

Accepted: July 31, 2015

Published: August 12, 2015

Citation: H.S.Natraj Setty, Vijayalakshmi IB, Narasimhan C, Manjunath CN (2015) Iatrogenic Right Sided Infective Endocarditis In Children With CHD. Int J Cardiol Res. 02(3), 34-36. doi: http://dx.doi. org/10.19070/2470-4563-150008

Copyright: H.S.Natraj Setty ${ }^{\circ}$ 2015. This is an open-access article distributed under the terms of the Creative Commons Attribution License, which permits unrestricted use, distribution and reproduction in any medium, provided the original author and source are credited.

\section{Background}

Right sided IE is a rare but well defined clinical entity in intravenous drug users, patients with pace makers or central venous line and with CHD [1, 2]. Right side endocarditis accounts for only $5 \%-10 \%$ of cases of IE. The majority of cases involve tricuspid valve and pulmonary valve $[3,4]$. Characteristic of isolated right sided IE in patients without a pacemaker and who are not intravenous drug users are poorly understood [5]. In this small series of four cases, we report children with involvement of the right sided IE secondary to IV lines used for injections and IV fluids. The clinical, microbiological, echocardiographic and prognostic profile is described.

The aim is to report clinical, microbiological and echocardiographic features of iatrogenic right sided IE in 4 children.

\section{Materials and Results}

Four cases of right sided IE who had presented between Sept 2013 to November 2013, age ranging from 1 month to 5 years, three females and one male formed the material. Two cases had VSD, one had a small ASD and one patient had TOF. They were very sick and moribund, presented with fever, breathlessness, chest pain and cough. All the four patients had history of prior admission to local hospitals, 15 days to 1 month prior for various conditions, other than CHD. Two cases were admitted and treated for lower respiratory tract infections (LRTI), one was for 
acute gastroenteritis and another for dengue fever. Anemia and leucocytosis was present in 3 children and the one patient of TOF with dengue fever had polycythemia, leucopenia and thrombocytopenia and was treated in children's hospital with IV fluids, blood and platelet infusions. On admission to our hospital they were examined thoroughly, meticulously investigated and detailed echocardiography was carried out. The bacteria detector (Vitek 2 Compact Biomerieux) detected coagulase negative staphylococcus in two patients and gram negative bacilli in the one patient. In another case multiple blood samples were negative. The diagnosis of tricuspid valve endocarditis (Figure 1, Video 1) was established by transthoracic echocardiography (T'TE) in all the four patients. One patient had vegetation in IVC (Figure 2) and in another case of VSD, large vegetation was seen closing the VSD (Figure 3, Video 2) and also large highly mobile vegetation (26X20mm) attached to ATL (Figure 4). Two antibiotics were given according to the sensitivity report. In two patients, with very large vegetation were referred for surgery. Only one patient was discharged after 6 weeks of antibiotics while 3 patients died (75\%). The demographic details of all the four cases is given in Table I.

\section{Discussion}

Right sided endocarditis accounts for only 5 - $10 \%$ of cases of IE. Its clinical presentation differs from left sided IE. It has been estimated that up to $76 \%$ of cases of endocarditis among IV drug abusers involve the right heart, compared with only $9 \%$ in non-addict patients. In most series Staphylococcus aureus, accounting for around $70-90 \%$ of infections, with the remainder being caused mainly by streptococcal species. The coagulase negative staphylococcus was isolated in two of our patients. Traditionally surgery is indicated in: 1) Uncontrolled septicemia 2) Fever $>3$ weeks 3) Intractable CCF 4) Repeated occurrence of pulmonary embolism 5) vegetation $>20 \mathrm{~mm}$ 6) Concomitant left sided IE. Though our first patient had many indications for surgery, but was not operated (as consent was not given). But the patient survived and was discharged on the 49th day. Little information is available regarding the recent development of right sided IE [6]. The bacterial endocarditis is extremely rare in cases of ASD and TOF. This series of four cases is notable for the iatrogenic IE of tricuspid valve in children treated in the reputed hospital with IV injections for various unrelated conditions. The infection in this series occurred upon previously normal tricuspid valve. In our patients, IV lines for parental injection or the IV fluids were the probable culprits. In all the four patient T'TE clinched the diagnosis of tricuspid valve vegetation causing tricuspid stenosis and regurgitation. These cases illustrate the importance of aseptic IV lines in children with underlying heart disease. Mortality in nosocomial infection is very high. Hence extra care must be taken while administering IV treatment in children with underlying heart diseases.

\section{Conclusion}

Right sided endocarditis can occur in CHD patients when proper aseptic precautions are not taken while treating with IV injections. Mortality in iatrogenic right sided endocarditis is very high. Hence the timely blood culture and TTE are very important in diagnosis

Figure 1. Apical four chamber view shows huge vegetation on tricuspid valve. Color Doppler shows tricuspid stenosis and regurgitation.

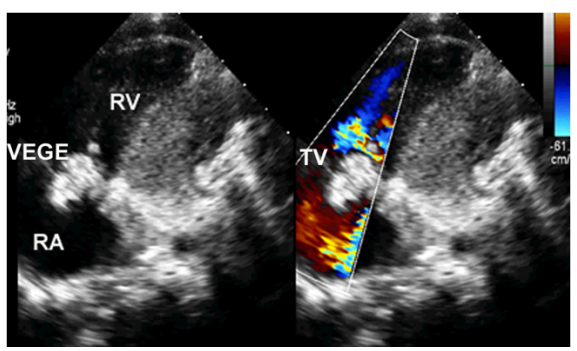

Figure 2. TTE in subcostal view shows vegetation in IVC

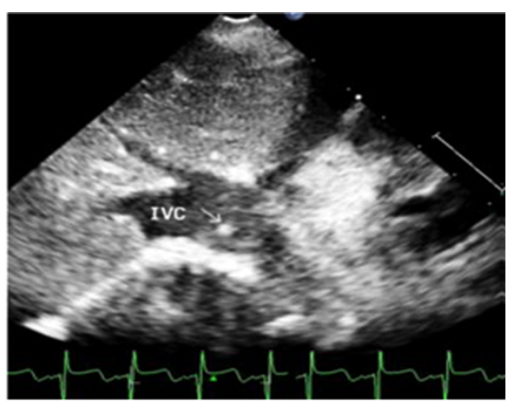

Figure 3. TTE in parasternal long axis view shows VSD closed by huge vegetation.

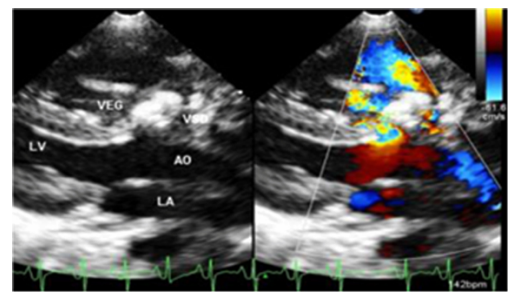


Figure 4. TTE in a one year old girl of VSD, with flail ATL, and severe TR, PAH, showed large highly mobile vegetation $(26 X 20 \mathrm{~mm})$ attached to ATL and note the grossly dilated right atrium with inter atrial septum bulging towards left atrium.

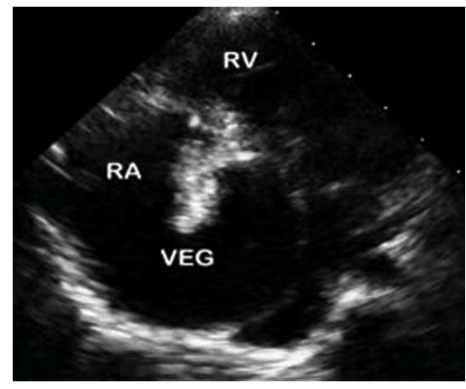

Table 1: Demographic profile of all four cases.

\begin{tabular}{|c|c|c|c|c|c|c|}
\hline Sl no & $\begin{array}{c}\text { Age/Sex/ } \\
\text { Weight (kgs) }\end{array}$ & $\begin{array}{l}\text { Clinical } \\
\text { History }\end{array}$ & $\begin{array}{l}\text { Previously } \\
\text { admitted }\end{array}$ & ECHO diagnosis & $\begin{array}{c}\text { Blood C/S and } \\
\text { treatment }\end{array}$ & End result \\
\hline 1 & $5 \mathrm{yr} / \mathrm{M} / 12$ & $\begin{array}{l}\text { Fever since } 20 \\
\text { days, dyspnea } \\
\text { palpitations, } \\
\text { fatigue since } 1 \\
\text { month }\end{array}$ & $\begin{array}{l}\text { Gastroenteritis } \\
15 \text { days back }\end{array}$ & $\begin{array}{l}\text { CHD, SS, small } \\
\text { perimembraneous } \\
\text { VSD with septal } \\
\text { aneursym, severe } \\
\text { TR, large vegeta- } \\
\text { tion on tricuspid } \\
\text { valve with mild } \\
\text { pericardial effu- } \\
\text { sion }\end{array}$ & $\begin{array}{l}\text { Coagulase Nega- } \\
\text { tive staphylococcus. } \\
\text { Treated with IV } \\
\text { Tigecycline, Clinda- } \\
\text { mycin, vancomycin, } \\
\text { cefeparazone }\end{array}$ & $\begin{array}{l}\text { Discharged } \\
\text { after } 6 \text { weeks } \\
\text { of antibiotics. } \\
\text { Total hospital } \\
\text { stay - } 49 \text { days }\end{array}$ \\
\hline 2 & $1 \mathrm{yr} / \mathrm{F} / 7.7$ & $\begin{array}{c}\text { Fever since } 1 \\
\text { month, re- } \\
\text { current LRTI } \\
\text {, breathless- } \\
\text { ness since } 6 \\
\text { months }\end{array}$ & $\begin{array}{l}\text { LRTI } 1 \text { month } \\
\text { back }\end{array}$ & $\begin{array}{l}\text { CHD SS, moder- } \\
\text { ate sized perimem- } \\
\text { braneous VSD, } \\
\text { flail ATL, severe } \\
\text { TR, PH, large } \\
\text { highly mobile veg- } \\
\text { etation attached to } \\
\text { ATL }\end{array}$ & $\begin{array}{l}\text { Coagulase nega- } \\
\text { tive staphylococcus. } \\
\text { Treated with IV } \\
\text { Tigecycline, Clinda- } \\
\text { mycin, Gentamicin }\end{array}$ & $\begin{array}{c}\text { Death post } \\
\text { operatively } \\
\text { due to septic } \\
\text { shock. } \\
\text { Total hospital } \\
\text { stay -11 days }\end{array}$ \\
\hline 3 & $1.11 \mathrm{yr} / \mathrm{F} / 7$ & $\begin{array}{c}\text { Cyanotic } \\
\text { spells, fever, } \\
\text { cough since } 1 \\
\text { week. Persis- } \\
\text { tent thrombo- } \\
\text { cytopenia } \\
\end{array}$ & $\begin{array}{c}\text { Dengue fever } 1 \\
\text { month back }\end{array}$ & $\begin{array}{c}\text { Cyanotic CHD, } \\
\text { TOF absent LPA, } \\
\text { OS ASD (5mm), } \\
\text { large vegetation } \\
\text { on tricuspid valve } \\
\text { with severe TR }\end{array}$ & $\begin{array}{l}\text { No bacterial growth. } \\
\text { Treated with IV } \\
\text { Meropenam and } \\
\text { ceftriaxone }\end{array}$ & $\begin{array}{c}\text { Death (PTE } \\
\text { with sepsis) } \\
\text { Total hospital } \\
\text { stay - } 13 \text { days }\end{array}$ \\
\hline 4 & $\begin{array}{c}1 \text { month / } \\
\text { F/2.9 }\end{array}$ & $\begin{array}{l}\text { Fever since } \\
1 \text { week with } \\
\text { cough and } \\
\text { chest retrac- } \\
\text { tions }\end{array}$ & $\begin{array}{l}\text { LRTI } 3 \text { days } \\
\text { back }\end{array}$ & $\begin{array}{l}\text { CHD SS, Large } \\
\text { OS ASD, bidi- } \\
\text { rectional shunt, } \\
\text { severe TR, with } \\
\text { chordal tear, } \\
\text { severe PH, large } \\
\text { mobile vegetation } \\
\text { on tricuspid valve }\end{array}$ & $\begin{array}{l}\text { Klebsiella pneumo- } \\
\text { nia Treated with IV } \\
\text { Meropenam and } \\
\text { ceftriaxone }\end{array}$ & $\begin{array}{l}\text { Death due to } \\
\text { sepsis } \\
\text { Total hospital } \\
\text { stay -5 days }\end{array}$ \\
\hline
\end{tabular}

ATL - Aanterior Tricuspid Leaflet; ASD - Atrial Septal Defect; CHD - Congenital Heart Disease; LPA - Left Pulmonary Artery; LRTI - Lower Respiratory Tract Infection; OS - Ostium Secundum; PH - Pulmonary Hypertension; PTE - Pulmonary Thrombo Embolism; SS - Situs Solitus; TOF - Tetralogy of Fallot; TR - Tricuspid Regurgitation.

and management on a war footing.

\section{References}

[1]. Robbins MJ, Soeiro R, Frishman WH, Strom JA (1986) Right-sided valvular endocarditis: etiology, diagnosis, and an approach to therapy. Am Heart J 111(1): 128-135.

[2]. Cosson S, Kevorkian JP, Milliez P, Beaufils P, Cohen A (2003) A rare localization in right-sided endocarditis diagnosed by echocardiography: A case report. Cardiovascular Ultrasound 1: 10.

[3]. Chan P, Ogilby JD, Segal B (1989) Tricuspid valve endocarditis. Am Heart
J 117(5): 1140-1146.

[4]. Frontera JA, Gradon JD (2000) Right-Side Endocarditis in Injection Drug Users: Review of Proposed Mechanisms of Pathogenesis. Clin Infect Dis 30(2): 374-379.

[5]. Revilla A, López J, Villacorta E, Gómez I, Sevilla T, et al. (2008) Isolated right-sided valvular endocarditis in non-intravenous drug users. Rev Esp Cardiol 61(12): 1253-1259.

[6]. Yuan SM (2014) Right sided infective endocarditis: recent epidemiologic changes. Int J Clin Exp Med 7(1): 199-218. 